\title{
Effect of growth regulators and soil media on the propagation of Voacanga africana stem cuttings
}

\author{
Ibrahim Hakeem Kontoh [
}

Received: 26 December 2014/ Accepted: 8 October 2015/Published online: 30 October 2015

(C) The Author(s) 2015. This article is published with open access at Springerlink.com

\begin{abstract}
In Ghana, riverine forests (riparian buffers) have been seriously degraded resulting in drying up of several rivers, which supply water to certain communities, especially in the rural areas. Restoration of these degraded lands is mostly done using exotic tree species which have the tendency to colonize and dominate indigenous tree species and eventually lead to loss of biodiversity. This research therefore examines the propagation of Voacanga africana tree species which could be used to protect water bodies and restore biodiversity loss. An experiment was conducted at the Faculty of Agriculture and Renewable Natural Resources lath house in Kwame Nkrumah University of Science and Technology. The objective was to test the efficiency of different growth media and hormones to improve rooting. The experiment consisted of three wood types of $V$. africana (hardwood, semi-hardwood and softwood), raised in three soil types (topsoil, sand and mixture of topsoil and sand) and treated with three growth hormones [Indobutyric acid (IBA), IBA + Naphthalene acetic acid (NAA) and Control]. The results showed that, hardwood and semi-hardwood cuttings of $V$. africana performed better in terms of sprouting and rooting. Dip'N'grow
\end{abstract}

I. H. Kontoh ( $\square)$

Department of Agroforestry, Faculty of Renewable Natural Resources, Kwame Nkrumah University of Science and Technology, Kumasi, Ghana

e-mail: ihakeemko@gmail.com (an IBA/NAA premix) was the best among the growth hormones. Seradix ' 3 ' powder (NAA) was also consistent. Among the growing media, materials raised in a mixture of topsoil and sand performed better than any of the soil types alone. Semi-hardwood and hardwood cuttings without hormone treatment (control) or treated with dip ' $n$ ' grow in a mixture of topsoil and sand should be considered for future propagation of $V$. africana stem cuttings.

Keywords Propagation - Growth hormones ·

Biodiversity $\cdot$ Restoration

\section{Introduction}

The degradation of catchment areas and watersheds has been cited as one of the major environmental hazards that has received little attention (Abeney 1998). Scherr (1991) in an assessment of 148 watersheds globally, emphasized that expanding human demands for resources have intensified watershed degradation with the result that some watersheds with the greatest biological production are becoming the most seriously degraded. In the tropics however, it is estimated that about 0.5 hectares of farmland is needed to feed one person (Lal 1997), has indicated that by the year 2025, 45 countries in the tropics will have $<0.1$ ha of arable land per capita. According to the Ghana National Biodiversity Strategy Report, 2002, 
biological resources in the country have been negatively impacted by increasing pressure from agricultural expansion, mining and timber extraction. In Ghana, riverine forests have been degraded by anthropogenic activities such as logging, farming, urbanization and mining. This has resulted in the drying up of several rivers which supply water to certain communities, especially in the rural areas as a result of decreased rainfall and its effect on catchment water productivity. Attempts have been made to restore degraded lands surrounding most rivers by several organizations, NGO's and certain communities (Hawthorne 1995).

Generally, the tree species commonly used for the restoration of the degraded vegetation are Tectona grandis (teak) and Acacia spp., both of which are exotic. The continuous use of these exotic species may endanger the development of biodiversity in the country in the near future if not reviewed. This is because, certain exotic species have the tendency to colonise a reasonable proportion of land within a very short period of time. This inhibits the development of indigenous tree species and results in the loss of biodiversity (Hawthorne 1995). Besides, the trees do not provide long-term protection to the rivers because they are harvested as timber or fuel wood at maturity. Many indigenous trees and shrubs are being used in different Agroforestry systems in the developing world (Nair 1988). V. africana was selected because it's a very common indigenous species in Ghana. Most of these woody perennials have multiple uses, and wherever grown, they are highly valued by the local farmers. However, very little scientific knowledge is available on the growth and management needs of these species. With the prevailing high demand for Agroforestry species, there is a growing need for developing simple and easy methods of growing such indigenous woody species such as $V$. africana. Some research has been done on this species using the seeds but detailed work using the vegetative parts including the addition of growth hormones is a novelty.

This study was therefore an attempt to provide nursery and agronomic characteristics of some indigenous tree species that could be used for plantation establishment to serve as buffers in degraded areas along water bodies in the transitional zone of Ghana. The specific objective was therefore to study the response of $V$. africana wood types to soil and growth regulator application.

\section{Materials and methods}

The study was conducted at the Department of Horticulture of the Kwame Nkrumah University of Science and Technology, Kumasi (KNUST), Ghana. The area falls within the moist semi-deciduous forest zone of Ghana and receives a bimodal rainfall, with the major wet season between May and July. This area experiences two dry periods: in August and in December to March. The average annual rainfall ranges between 1200 and $1500 \mathrm{~mm}$ with a mean annual temperature of $26.6^{\circ} \mathrm{C}$ and a mean annual humidity of $67.6 \%$. The soils are classified as ferric acrisol (FAO 1988) with a sandy-loam textural class.

Experimental design and sampling procedure

All the Voacanga propagation plant materials for the experiment were collected from the wild at Anwomaso, a suburb of Kumasi and Kokofu in the Amansie East District of the Ashanti region. All the plant propagation materials were obtained from mature (5-15 years) and juvenile (4-10 years) trees. The types of planting materials used were:

Softwood (made up of soft and succulent parts of Voacanga trees which were produced at the tip of the branches during the rainy season); Semi-hardwood (partially matured and slightly woody); Hardwood (fully matured brownish and woody parts of V. africana trees). Propagation materials used in the experiments were the black polythene nursery bags (Exp. 1 and 2) and the polythene propagator (Exp. 2), they were both placed under the lath house at the College of Agriculture and Natural Resources. Three types of soil media (top soil, sand and mixture of topsoil and sand) were used for the various experiments. Topsoil, eutric leptsol (FAO 1990) collected from the adjoining lands of the College of Agriculture was from the soil surface to a depth of $20 \mathrm{~cm}$. Sand was collected from the banks of a small stream at the Faculty of Natural Resources experimental farm at KNUST. The topsoil and sand were mixed at a ratio of $1: 1$. They were thoroughly mixed before it was set. The various soil media were put in black polythene nursery bags $(15 \times 25 \mathrm{~cm})$ and watered a day before setting the cuttings to prevent the soil from hardening up. Stem cuttings of the various wood types (Softwood, semihardwood and hardwood) cuttings of $V$. africana were $15 \mathrm{~cm}$ long and a diameter of between 0.5 and $1.5 \mathrm{~cm}$ 
with an average of about three nodes on each cutting. The freshly prepared cuttings were put in transparent polythene sacks to prevent desiccation. The base of two-third of the cuttings up to $2 \mathrm{~cm}$ was dipped in rooting medium concentrations for $20 \mathrm{~s}$ and allowed to dry for $10 \mathrm{~s}$ before inserting them in the nursery bags. Watering of the hormone treated cuttings was done after setting cuttings in the medium. The other quarter of the propagation cutting materials was used as control. Rooting hormones used were Dip 'N' Grow [already manufactured: $5000 \mathrm{ppm}$ naphthalene acetic acid (NAA), 10,000 ppm Indobutyric acid (IBA) and boron] and Seradix " 2 " powder (IBA (active ingredient). The parameters studied include above ground (number of sprouts and leaf width) and below ground (number of roots and average root length).

\section{Experimental procedure}

The experiment was set up in a Completely Randomized Design with the main plot factor being the soil media (top soil, mixture of topsoil and sand, sand), the sub-plot factor was the growth regulators (no hormone-control, Seradix '2' and Dip 'N' grow), and the sub-sub-plot factor was the wood types (softwood, semi-hard wood, hardwood). These gave twentyseven treatment combinations. Ten cuttings were used per each treatment combination and these were replicated three times.

\section{Nursery management practices}

Watering was done once every 2 days in the morning with 36 liters of water. The quantity and volume of water was determined through the measurement of soil moisture content and soil temperature. The soil moisture was measured using a soil moisture sensor (0.2-0.5/vol.). A soil thermometer was used to measure an average soil temperature of $24^{\circ} \mathrm{C}$. Fallen, infected and dead cuttings were removed daily to avoid spreading of diseases. Daily picking out of weeds was done to avoid competition with the cuttings for nutrients. The nursery bags were encircled with wood ash to prevent snails from destroying the cuttings.

Data analysis

Microsoft Excel program was use to enter and manage the data as well as plot graphs. The data was then analysed using and MSTATC statistical software package. Data on number of sprouted cuttings, leaf width, number of roots and root length measurement of Voacanga cuttings were subjected to Split-split factorial Analysis of variance (ANOVA) and the differences between the means were compared using Least Squared Difference (LSD).

\section{Results}

Main effects of soil types, growth regulator (G.R) application and wood types on the performance of cuttings

Table 1 shows that cuttings that were set in sand and mixture of topsoil and sand were not different from each other in terms of the number of sprouts produced. However, cuttings from each of the above soil types produced more sprouts than cuttings set in topsoil alone. Cuttings that were set in a mixture of topsoil and sand produced the highest number of leaves on the average whiles cuttings set in topsoil alone gave the least number of leaves on the average. The leaf width obtained from all the three soil types was not significant $(\mathrm{P} \leq 0.05)$ but topsoil and sand mixture gave the longest leaf width.

There was no significant $(\mathrm{P}>0.05)$ effect of the soil types on the average root length but topsoil produced the highest value on the average for root length whiles topsoil and sand mixture produced the least root length on the average. Growth regulator (G.R) application did not significantly $(\mathrm{P}>0.05)$ affect the number of sprouts developed but Dip 'N'grow produced more sprouts than Seradix ' 3 ' powder and control with control having the least number of sprouts (plate 4.2). Cuttings which had no hormone application (control) had the highest number of leaves on the average whiles Dip 'N'grow produced the least number of leaves on the average. There was significant $(\mathrm{P}<0.05)$ effect of G.R. application on the leaf width. Cuttings which had no hormone treatment (control) and Seradix ' 3 ' powder were significantly $(\mathrm{P}<0.05)$ different from each other, however, they were lower than Dip 'N'grow which had the highest value for leaf width. The effect of G.R. application on the number of roots per cutting was significant $(\mathrm{P}<0.05)$. Dip 'N'grow produced the highest number of roots per cutting whiles Seradix '3' powder and cuttings which had 
Table 1 Main effects of growing media, growth regulator application and wood types on the performance of Voacanga africana cuttings

\begin{tabular}{|c|c|c|c|c|}
\hline Treatments & Number of sprouts & Leaf width $(\mathrm{cm})$ & Number of roots/cutting & Average root length $(\mathrm{cm})$ \\
\hline \multicolumn{5}{|l|}{ Soil types } \\
\hline Top soil & 1.5 & 1.1 & 4.9 & 1.6 \\
\hline Sand & 3.0 & 1.1 & 8.4 & 1.4 \\
\hline Top + Sand & 3.3 & 1.9 & 10.3 & 1.1 \\
\hline $\operatorname{LSD}_{(0.05)}$ & 0.6 & ns & 0.8 & ns \\
\hline \multicolumn{5}{|l|}{ G.R. application } \\
\hline Control & 2.4 & 1.3 & 7.6 & 1.4 \\
\hline Seradix ' 3 ' powder & 2.6 & 1.2 & 7.8 & 1.0 \\
\hline Dip 'N' grow & 2.8 & 1.6 & 8.1 & 1.8 \\
\hline $\operatorname{LSD}_{(0.05)}$ & ns & ns & 1.5 & ns \\
\hline \multicolumn{5}{|l|}{ Wood types } \\
\hline Hardwood & 3.2 & 1.9 & 9.1 & 2.5 \\
\hline Semi-hard wood & 3.2 & 1.3 & 8.1 & 1.3 \\
\hline Softwood & 1.3 & 0.8 & 0.2 & 0.5 \\
\hline $\operatorname{LSD}_{(0.05)}$ & ns & ns & 0.9 & ns \\
\hline
\end{tabular}

$n s$ Not significant

hormone treatment (control) had the least value. Cuttings which were treated with Dip'N'grow produced the longest root length on the average while Seradix ' 3 ' powder had the least value for root length on the average.

There were no significant $(\mathrm{P}<0.05)$ differences in wood types on the average number of sprouts produced. The number of sprouts produced from hardwood and semi-hardwood were not significantly $(\mathrm{P}<0.05)$ different from each other but was higher than the number obtained from softwood. The highest number of leaves on the average was obtained from semi-hardwood cuttings whiles the least number was obtained from softwood cuttings. The wood types also had no significant $(\mathrm{P}<0.05)$ effect on the leaf width. Hardwood cuttings produced the highest value for leaf width whiles the least value was obtained from softwood cuttings. There was significant $(\mathrm{P}>0.05)$ differences in with regards to the wood types on the number of roots per cutting developed. The hardwood cuttings produced the highest number of roots whiles the softwood cuttings produced the lowest number. Average root length obtained from semi-hardwood cuttings was higher than that of softwood.

Table 2 shows that significant $(\mathrm{P}>0.05)$ interaction existed among the treatments. Treatment interaction between wood types and growth regulator application significantly $(\mathrm{P}>0.05)$ affected the number of sprouts. Softwood cuttings which had no hormone treatment (control) had the highest number of sprouts whiles hardwood cuttings treated with Dip ‘ $N$ 'grow produced the least number of sprouts.

The treatment interactions also had significant $(\mathrm{P}>0.05)$ effect on the average number of leaves. Hardwood cuttings treated with Seradix ' 3 ' powder produced the highest number of leaves on the average whiles the least number was recorded by softwood cuttings treated with Dip'N'grow. There was no significant $(\mathrm{P}<0.05)$ effect of treatment interaction on the leaf width, number of roots per cutting developed and the average root length. However, the highest number for leaf was recorded by semihardwood cuttings which had no hormone application (control) and the least number produced by hardwood cuttings treated with Dip 'N'grow.

Hardwood and semi-hardwood cuttings treated with both Seradix '3'powder and Dip'N'grow produced the highest number of roots per cutting whiles softwood cuttings treated with Seradix ' 3 ' powder, Dip'N'grow and control (no hormone) recorded the least values.

Semi-hardwood cuttings treated with Seradix ' 3 'powder recorded the highest value for average root length whiles softwood cuttings with all the 
Table 2 Treatment interaction effects on wood types and growth regulator applications on the performance of Voacanga africana cuttings

\begin{tabular}{|c|c|c|c|c|}
\hline Wood types/G.R. application & Number of sprouts & Leaf width $(\mathrm{cm})$ & Number of roots/cutting & Average root length $(\mathrm{cm})$ \\
\hline Hardwood $*$ Control & 3.0 & 1.5 & 0.0 & 0.3 \\
\hline Hardwood * Seradix ‘3’ powder & 3.0 & 1.5 & 1.0 & 1.3 \\
\hline Hardwood * Dip'N'grow & 1.0 & 0.8 & 2.0 & 2.6 \\
\hline Semi-hardwood $*$ Control & 3.0 & 2.1 & 0.3 & 0.3 \\
\hline Semi-hardwood * Seradix ‘3’powder & 3.0 & 0.9 & 1.0 & 1.0 \\
\hline Semi-hardwood * Dip‘N'grow & 1.0 & 0.7 & 2.0 & 1.7 \\
\hline Softwood $*$ Control & 4.0 & 2.2 & 1.0 & 0.8 \\
\hline Softwood * Seradix ‘3’ powder & 3.0 & 1.5 & 2.0 & 1.4 \\
\hline Softwood * Dip`N’grow & 2.0 & 1.0 & 2.0 & 3.2 \\
\hline Interaction $\operatorname{LSD}_{(0.05)}$ & 0.7 & ns & ns & $\mathrm{ns}$ \\
\hline
\end{tabular}

* Interaction between treatments

$n s$ Not significant

Table 3 Treatment interaction effects of wood types and growing media on the performance of Voacanga africana cuttings

\begin{tabular}{lllll}
\hline Wood types/soil types & Number of sprouts & Leaf width $(\mathrm{cm})$ & Number of roots/cutting & Average root length $(\mathrm{cm})$ \\
\hline Hardwood * Topsoil & 2 & 1.6 & 6.0 & 0.6 \\
Hardwood * Sand & 2 & 1.2 & 4.0 & 1.0 \\
Hardwood * Top + Sand & 1 & 0.5 & 5.0 & 3.0 \\
Semi-hardwood * Topsoil & 4 & 1.8 & 11.0 & 0.3 \\
Semi-hardwood * Sand & 4 & 0.7 & 8.0 & 1.1 \\
Semi-hardwood * Top + Sand & 2 & 0.8 & 6.0 & 2.1 \\
Softwood * Topsoil & 4 & 2.4 & 11.0 & 0.6 \\
Softwood * Sand & 4 & 2.0 & 12.0 & 1.7 \\
Softwood * Top + Sand & 2 & 1.3 & 8.0 & 2.3 \\
Interaction LSD $(0.05)$ & $\mathrm{ns}$ & $\mathrm{ns}$ & 1.5 & $\mathrm{~ns}$ \\
\hline
\end{tabular}

* Interaction between treatments

ns Not significant

three treatments recorded no value. Treatment interactions between wood types and soil types did not have any significant effect $(\mathrm{P}<0.05)$ have any significant effect on the number of sprouts, average number of leaves, leaf width and average root length except number of roots per cutting developed (Table 3). Semi-hardwood and softwood cuttings set in topsoil alone and sand alone produced the highest number of sprouts whiles hardwood cuttings set in a mixture of topsoil and sand recorded the least number of sprouts. Hardwood cuttings set in sand recorded the highest value for average number of leaves whereas hardwood and softwood cuttings set in a mixture of topsoil and sand produced the least number of leaves. Softwood cuttings set in topsoil recorded the highest value for leaf width whiles hardwood cuttings set in a mixture of topsoil and sand gave the lowest value for leaf width. Hardwood cuttings set in sand produced the highest number of roots per cutting, whiles softwood cuttings set in sand produced the least number of roots per cutting. Average root length of hardwood cuttings set in a mixture of topsoil and sand produced the highest value while softwood cuttings 
set in sand alone gave the least value. Table 4 shows that there was no significant $(\mathrm{P}<0.05)$ interaction effect of soil types and growth regulator application on the parameters except the number of sprouts and the number of roots developed. Cuttings set in sand and treated with Dip'N'grow as well as cuttings set in a mixture of topsoil and sand without hormone treatment (control) produced the highest number of sprouts. The least number of sprouts was recorded by cuttings set in a mixture of topsoil and sand which had no hormone treatment (control).

Cuttings which were set in a mixture of topsoil and sand without hormone treatment (control) recorded the highest number of leaves on the average whiles cuttings set in topsoil and treated with Dip'N'grow had the least value for average number of leaves. A mixture of topsoil and sand with Dip 'N'grow gave the highest value for leaf width, number of roots and the average root length. Cuttings set in topsoil without hormone treatment (control) recorded the lowest value for leaf width and number of roots. Cuttings treated with Seradix ' 3 ' powder and set in a mixture of topsoil and sand and sand alone gave the least value for average root length. Table 5 shows the three-factor interaction between soil types, hormone application and wood types. The number of sprouts, leaf width and the number of roots per cutting developed were significantly $(\mathrm{P}<0.05)$ different among the treatment interactions. However, no consistent pattern was observed between the interactions and the parameters studied.

\section{Discussion}

The analysis of the experiment conducted on $V$. africana cuttings using three soil, growth regulator and wood types indicated that, semi-hardwood cuttings recorded the highest $(\mathrm{P}>0.05)$ number of sprouts and rooting per cutting than softwood and hardwood types. The high number of sprouts and roots developed could be attributed to their physiological age or juvenility. This is due to the fact that, better rooting results are obtained from cuttings taken from young trees 2-10 years of age as compared to cuttings taken from trees which are over 40 years of age (Hartmann and Hansen 1958). Again, it has been observed that the presence of carbohydrates in the cuttings help in the growth and development of roots as well as sustain the cutting while it is in the medium. Wiegel et al. (1984) has also reported that carbohydrates also enhance metabolic activities that occur at the base of the cuttings to aid cell division which brings about root initiation.

Mixture of topsoil and sand in all the experiments produced more $(\mathrm{P}>0.05)$ sprouts and roots than the other soil media used. IFCC (1972) report has indicated that, the effect of various media on the performance of cuttings is closely associated with temperature and water relation. A medium temperature of $25-26{ }^{\circ} \mathrm{C}$ in the morning and $27-30{ }^{\circ} \mathrm{C}$ in the afternoon could enhance germination and rooting (Cheesman and Spencer 1936). An average soil temperature of $24{ }^{\circ} \mathrm{C}$ was recorded before planting

Table 4 Treatment interaction effects on growing media and growth regulators on the performance of Voacanga africana cuttings

\begin{tabular}{|c|c|c|c|c|}
\hline Soil/hormones & Number of sprouts & Leaf width $(\mathrm{cm})$ & Number of roots/cutting & Average root length $(\mathrm{cm})$ \\
\hline Topsoil * Control & 1.3 & 0.8 & 4.0 & 1.2 \\
\hline Topsoil * Seradix ‘3’ powder & 1.6 & 1.3 & 4.9 & 1.4 \\
\hline Topsoil * Dip`N’grow & 1.6 & 1.3 & 6.0 & 1.9 \\
\hline Sand *Control & 2.4 & 0.9 & 9.1 & 1.4 \\
\hline Sand * Seradix ‘3’powder & 3.2 & 1.3 & 8.7 & 0.8 \\
\hline Sand * Dip'N’grow & 3.5 & 1.1 & 7.4 & 1.3 \\
\hline Top +Sand $*$ Control & 3.5 & 2.1 & 9.9 & 1.6 \\
\hline Top + Sand * Seradix‘3’powder & 3.3 & 1.2 & 10.0 & 0.8 \\
\hline Top + Sand * Dip'N'grow & 3.3 & 2.4 & 11.0 & 2.2 \\
\hline Interaction $\operatorname{LSD}_{(0.05)}$ & 0.7 & ns & 1.5 & ns \\
\hline
\end{tabular}

* Interaction between treatments

ns Not significant 
Table 5 Treatment interaction effects on growing media, growth regulators and wood types on the performance of Voacanga africana cuttings

\begin{tabular}{|c|c|c|c|c|}
\hline Soil/G.R/wood types & $\begin{array}{l}\text { Number of } \\
\text { sprouts }\end{array}$ & $\begin{array}{l}\text { Leaf width } \\
(\mathrm{cm})\end{array}$ & $\begin{array}{l}\text { Number of } \\
\text { roots/cutting }\end{array}$ & $\begin{array}{l}\text { Average root } \\
\text { length }(\mathrm{cm})\end{array}$ \\
\hline Topsoil $*$ Control $*$ Hardwood & 2.0 & 0.9 & 5.0 & 0.3 \\
\hline Topsoil * Control * Semi-hardwood & 1.4 & 0.9 & 4.0 & 1.0 \\
\hline Topsoil $*$ Control $*$ Softwood & 0.6 & 0.6 & 3.0 & 2.3 \\
\hline Topsoil * Seradix ‘3’ powder * Hardwood & 1.3 & 2.1 & 7.0 & 0.3 \\
\hline Topsoil * Seradix ‘3’ powder * Semi-hardwood & 2.3 & 1.2 & 2.0 & 1.0 \\
\hline Topsoil * Seradix ‘3’ powder * Softwood & 1.2 & 0.5 & 6.0 & 3.0 \\
\hline Topsoil * Dip 'N’grow * Hardwood & 2.2 & 1.8 & 5.0 & 1.0 \\
\hline Topsoil * Dip‘N'grow * Semi-hardwood & 1.9 & 1.6 & 6.0 & 1.0 \\
\hline Topsoil * Dip‘N'grow * Softwood & 0.8 & 0.5 & 6.0 & 3.6 \\
\hline Sand $*$ Control $*$ Hardwood & 2.7 & 1.1 & 12.0 & 0.3 \\
\hline Sand $*$ Control* Semi-hardwood & 3.3 & 0.8 & 9.0 & 1.0 \\
\hline Sand $*$ Control $*$ Softwood & 1.2 & 0.8 & 6.0 & 3.0 \\
\hline Sand * Seradix ' 3 ' powder * Hardwood & 4.1 & 2.3 & 11.0 & 0.3 \\
\hline Sand $*$ Seradix ' 3 ' powder * Semi-hardwood & 3.8 & 0.8 & 9.0 & 1.3 \\
\hline Sand * Seradix '3' powder * Softwood & 1.6 & 0.7 & 6.0 & 0.7 \\
\hline Sand * Dip'N'grow * Hardwood & 4.7 & 2.0 & 10.0 & 0.3 \\
\hline Sand * Dip'N'grow * Semi-hardwood & 4.1 & 0.5 & 5.0 & 1.0 \\
\hline Sand * Dip'N'grow * Softwood & 1.6 & 0.8 & 7.0 & 2.7 \\
\hline Mixture * Control *Hardwood & 3.9 & 2.5 & 12.0 & 0.3 \\
\hline Mixture $*$ Control $*$ Semi-hardwood & 4.5 & 2.9 & 12.0 & 2.0 \\
\hline Mixture $*$ Control $*$ Softwood & 1.9 & 1.1 & 6.0 & 2.3 \\
\hline Mixture * Seradix '3' powder * Hardwood & 4.6 & 1.8 & 10.0 & 0.3 \\
\hline Mixture * Seradix ‘3’ powder * Semi-hardwood & 4.1 & 0.9 & 13.0 & 0.7 \\
\hline Mixture *Seradix ' 3 ' powder $*$ Softwood & 1.1 & 1.0 & 7.0 & 1.3 \\
\hline Mixture * Dip ‘N’grow * Hardwood & 3.5 & 2.9 & 11.0 & 1.0 \\
\hline Mixture * Dip'N'grow * Semi-hardwood & 4.3 & 2.4 & 12.0 & 2.3 \\
\hline Mixture * Dip'N'grow * Softwood & 2.1 & 1.8 & 9.7 & 3.3 \\
\hline $\operatorname{LSD}_{(0.05)}$ & ns & 0.7 & 2.6 & ns \\
\hline
\end{tabular}

* Interaction between treatments

$n s$ Not significant

that might have influenced the number of sprouts. Hardy (1960), also posited that, the suitability of a medium depended on the amount and frequency of water. These findings were observed with sand and topsoil mixture medium. A soil water content of between 0.2 and $0.5 / \mathrm{vol}$. was obtained during the preparation stage. The high aeration in the sand medium might have created a good environment for increased respiration at the base of the cuttings which encourages rooting as reported by Evans (1953). The results from the experiment also showed that cuttings which were treated with Dip 'N'grow produced more sprouts and roots than the other growth regulators. It has been suggested by Middleton et al. (1980) that, carbohydrate concentrations may be influenced by auxin treatment which can also enhance mobilization of carbohydrates in leaves, upper stem and increase transport to the rooting zone. Hitchcock and Zimmerman (1940) also observed that, auxin treatment results in high percentage rooting and the development of more roots per cutting. Apparently, the movement of boron (B), nitrogen $(\mathrm{N})$, zinc $(\mathrm{Zn})$ and potassium $(\mathrm{K})$ to the rooting zone as observed by Blazich et al. (1983) is enhanced by auxin treatment. 
Mixtures of root promoting substances are sometimes more effective than either compound alone. For example, equal parts of indolebutyric acid (IBA) and naphtaleneacetic acid (NAA) when used on a widely diverse species were found to induce a higher percentage of cuttings to give more roots per cutting than either auxin alone as stated by Ellyard (1981). It has also been observed by Davies and Haissig (1990) that, adding a small percentage of certain phenoxy compounds to either IBA or NAA increased rooting and produced root systems better than obtained with using phenyl compounds alone. According to Archibald (1953), Hartmann et al. (1997), an ideal rooting medium provides sufficient porosity to allow good aeration; has a high water retaining capacity but well drained and free from fungi and bacteria. In coarse sand, the roots produced are thick and brittle with few laterals. Such roots are readily broken when the plants are potted. However, a mixture of topsoil and sand produced more sprouts and roots the experiment. Among some of the rooting media used in Ghana is a mixture of equal part of coarse river sand and composted oil palm fiber. The fiber holds moisture while the sand keeps the mixture open and well aerated as stated by Brian (1962). On the contrary, equal parts of topsoil and sand are also good for rooting as evidenced in the experiment.

The greater sprouting percentage and the number of roots developed may probably be due to juvenility. All the cutting materials were obtained from young seedling plants in juvenile growth phase which according to Gardiner (1951) root more readily. Paton et al. (1970) also observed that juvenility in relation to rooting may possibly be explained by low levels of rooting inhibitors as well as high levels of photosynthates, but as the plant grows older, the inhibitor levels increases. The high number of sprouts and roots recorded from the wood types could also be attributed to the effect of buds on the cuttings. Buds on a cutting have a strong promoting effect on rooting as observed by Leopold (1960); Kozlowski and Kramer (1997). For root formation to occur the presence of an actively growing shoot tip (or lateral bud) is necessary during the first three or 4 days after the cuttings are made as stated by Haissig (1972).

Hess and Snyder (1957), indicates that rooting capacity is positively correlated with carbohydrate availability. The importance of carbohydrate-to- nitrogen $(\mathrm{C} / \mathrm{N})$ ratio in plant growth and development has been hypothesised by Wiegel et al. (1984). High $\mathrm{C} / \mathrm{N}$ ratio in cutting tissue promotes rooting but do not accurately predict the degree of rooting responses as observed by Struve (1981). The ability of a stem to root has been shown to be due to an interaction of inherent factors present in the stem cells as well as transportable substances produced in leaves and buds, the major one being carbohydrate with others as nitrogenous compounds and vitamins as reported by Jules et al. (1981).

Treatment interactions

Wood types and growth regulators interacted to give the highest number of roots per cutting for both hardwood and semi-hardwood cuttings treated with Seradix '3' powder and Dip 'N'grow. Semi-hardwood cuttings dipped in Dip 'N'grow produced more sprouts and the longest root length. The better performance of Dip'N'grow than the other hormones could be attributed to the fact that the mixtures of root promoting substances are sometimes more effective than either component alone. Hardwood and semihardwood types might have had high levels of carbohydrate and nitrogen concentration in them. Interaction effects of wood types and growing media was not significant for the parameters studied except for the number of roots per cutting where hardwood cuttings set in a mixture of topsoil and sand produced the highest number of roots. The high number of roots per cutting developed by hardwood cuttings in a mixture of topsoil and sand may be due to the fact that the topsoil holds moisture while the sand keeps the medium open and well aerated.

Interaction effects between hormone application and growing media did not give any significant difference on average number of leaves, leaf width and average root length except for the number of sprouts and roots per cutting developed, where cuttings dipped in a mixture of topsoil and sand, treated with Dip 'N'grow gave the highest number of sprouts and roots per cutting developed. The reason for the high numbers might have been due to the excellent moisture supply and the effectiveness of the mixture of the two root promoting substances.

Significant difference existed in the number of sprouts, leaf width and the number of roots in the three-factor interaction involving growing medium, 
growth regulator application and wood types. Hardwood cuttings dipped in sand and treated with Dip 'N'grow produced the highest number of sprouts which might have been due to effectiveness of the growth regulators and the excellent condition provided by the growing media. The high number of roots obtained from hardwood cuttings inserted in a mixture of topsoil and sand without hormone treatment (control) might be due to the optimum moisture supply provided by the growing medium and the possible high carbohydrate to nitrogen ratio concentration in the cuttings.

\section{Conclusion}

Based on the results of this research, the following conclusions were drawn; first, it is apparent that (i) hardwood and semi-hardwood cuttings of $V$. africana performed better in terms of sprouting and rooting in both experiments (ii) Dip 'N'grow was the best among the growth regulators, however, Seradix ' 3 ' powder was averagely consistent (iii) Cuttings set in a mixture of topsoil and sand performed better than those set in any of the growing media alone. The cuttings used in the experiments were taken during the flowering season. It is therefore recommended that further research should be done on $V$. africana tree using cuttings of different seasons that is, fruiting and harvesting to determine the best period to take its cuttings for propagation.

Also, further studies should be conducted to find out the performance of the Voacanga seedlings on the field, especially within the catchment area of the river in the study area. This will enable us to know whether the tree will be able to colonise the vegetation along the watershed and subsequently provide the needed shade and also check erosion among others. This research was conducted on only one multi-purpose tree species (MPTS) and as such recommend that more MPTS should be identified and research conducted on them to determine their growth characteristics. Moreover, micro-propagation using small parts of a tree such as the embryotissues among others should be studied. It is also recommended that a longer duration should be used for a more detailed and comprehensive research to be conducted on $V$. africana tree species.
Open Access This article is distributed under the terms of the Creative Commons Attribution 4.0 International License (http:// creativecommons.org/licenses/by/4.0/), which permits unrestricted use, distribution, and reproduction in any medium, provided you give appropriate credit to the original author(s) and the source, provide a link to the Creative Commons license, and indicate if changes were made.

\section{References}

Abeney EA (1998) Forestry education-meeting challenges in sustainable forestry development in the 21 st century. In: Proceedings of 20th international forestry student's symposium in Ghana, pp 1-8

Archibald JF (1953) Factors concerned in the rooting response of cuttings. Proceedings of West Africa international cacao research conference, pp 40-42

Blazich FA, Wright RD, Schanffer HE (1983) Mineral nutrition status of "convexa" holly cuttings during intermittent mist propagation as influenced by exogenous auxin application. J Am Soc Hort Sci 109:350-355

Brian WJ (1962) Agriculture and land use in Ghana. Oxford University Press, London

Cheesman EE, Spencer GEL (1936) The propagation of cuttings in tropical climate. Trop Agric 13:201-206

Davies TD, Haissig BE (1990) Chemical control of adventitious root formation in cuttings. Plant Growth Regul Soc Am Q $18(1): 1-12$

Ellyard RK (1981) Effect of auxin combinations on the rooting of Personia chamaepitys and P. pinfolia cuttings. Comb Proc Int Plant Propag Soc 31:251-255

Evans H (1953) Recent investigations on the propagation of cacao. Rep Cacao Res 1945-51:182-210

Food and Agriculture Organisation (FAO) (1990) Second level. Soil map of Ghana. CSIR, Soil Research Institute, Accra

Gardiner FE (1951) Growth substances in relation to the production of tree fruits. In: Skoog F (ed) Plant growth substances. University of Wisconsin Press, Madison, pp 207-223

Haissig BE (1972) Meristematic activity during adventitious root primordium development. Plant Physiol 49:889-892

Hardy F (1960) Cacao manual. Int Am Inst Agric Sci 3:134-158

Hartmann HT, Hansen CJ (1958) Effect of season of collecting, indolebutyric acid, and preplanting storage treatments on rooting of Marianna plum, peach, and quince hardwood cuttings. Proc Amer Soc Hort Sci 71:57-66

Hartmann HT, Kester DE, Davies FT, Genève RL (1997) Plant propagation principles and practices. Prentice Hall, New Jersey, pp 276-391

Hawthorne WD (1995) Ecological profiles of Ghanaian forest trees. Tropical forestry papers 29 . Oxford Forestry Institute, Department of Forest Sciences, University of Oxford Press, Oxford, pp 202-204

Hess CE, Snyder WE (1957) A physiological comparison of the use of mist with other propagation procedures used in rooting cuttings. In: Report on 14th International Horticulture Conference, Scheningen, vol 2, p 1133

Hitchcock AE, Zimmerman PW (1940) Effects obtained with mixture of root-inducing hormones and other substances. Contrib Boyce Thompson Inst 11:143-160 
Institute Francais de Cacao, Café (IFCC) (1972) (Antenne de Tamatave). Rapports mensuels. Nov. 1969 a Avril 1972

Jules J, Schery RW, Woods FW, Ruttan VW (1981) Plant science, an introduction to world crops, 3rd edn. W. H. Freeman and Company, San Francisco

Kozlowski TT, Kramer PJ (1997) Physiology of woody plants, 2nd ed. Academic Press, New York, pp 534-536

Lal R (1997) Residue management, conservation tillage, and soil restoration for mitigating greenhouse effect by $\mathrm{CO}_{2}^{-}$ enrichment. Soil and Tillage Research 43:81

Leopold AC (1960) Auxins and plant growth, 2nd edn. University of Carlifornia Press, Berkeley, $354 \mathrm{pp}$

Middleton W, Jarvis BC, Booth A (1980) The role of leaves in auxin and boron pendent on rooting of stem cuttings of Phaseous aureus Roxb. New Phytologist 84:287-297
Nair PKR (ed) (1988) Agroforestry Systems in the Tropics. Martins Nijhoff, The Hague

Paton DM, Willing RR, Nichols W, Pryor LD (1970) Rooting of stem cuttings of eucalyptus. Rooting inhibitor in adult tissue. Aust J Bot 18:175-183

Scherr SJ (1991) Methods of Participatory on-farm agroforestry research. ICRAF, Nairobi, p 72

Struve DK (1981) The relationship between carbohydrate and nitrogen in rooting of stem cutting. Plant Propag 27:6-7

Wiegel K, Horn H, Hock B (1984) Endogenous auxin levels in terminal stem cuttings of Chrysanthemum morifolium during adventitious rooting. Physiol Plant 61:422-428 